\title{
Conservation Challenges of Heritage Building Reuse in Nigeria: A review of decision-making models
}

\author{
Salim Bashir Umar ${ }^{1,2}$, Ismail Said 3 , \\ 1 Department of Architecture, Faculty of Built Environment, \\ Universiti Teknologi Malaysia, Johor Bahru, Malaysia \\ ${ }^{2}$ Department of Architecture,Faculty of Earth and Environmental Sciences, Bayero \\ University Kano, Nigeria. \\ ${ }^{3}$ Department of Landscape, Faculty of Built Environment, \\ Universiti Teknologi Malaysia, Johor Bahru, Malaysia
}

Sbumar81@gmail.com, ismailbinsaid@gmail.com

\begin{abstract}
African countries including Nigeria are enriched with heritage properties embraced with legacy and architectural values depicting sense of identity. They deserve to be conserved to future generations. However, the properties are continuously ignored and destroyed due to redundancy and injudicious decision. Hence, this paper aimed at reviewing decision-making models adopted mostly in developed countries for possible suitability in developing countries. Meta-analysis was conducted where eight decision-making models were deduced. Practical implications and limitations of the models were acknowledged. The findings were appropriately reviewed and harmonized to suit and enhance optimum quality of conserving heritage assets in developing countries.
\end{abstract}

Keywords: Conservation; Heritage buildings; Adaptive reuse; Decision-making models

eISSN 2514-751X @ 2019. The Authors. Published for AMER ABRA cE-Bs by e-International Publishing House, Ltd., UK. This is an open-access article under the CC BY-NC-ND license (http://creativecommons.org/licenses/bync-nd/4.0/). Peer-review under responsibility of AMER (Association of Malaysian Environment-Behaviour Researchers), ABRA (Association of Behavioural Researchers on Asians) and cE-Bs (Centre for EnvironmentBehaviour Studies), Faculty of Architecture, Planning \& Surveying, Universiti Teknologi MARA, Malaysia.

https://doi.org/10.21834/aje-bs.v4i12.336 


\subsection{Introduction}

Heritage buildings are valuable assets that have legacy potentials of the past. They are embedded with cultural artifacts, natural resources, artistic, architectural, historical, economic, and socio-cultural values. Hence, they play a significant role in social and economic dynamics, both in developed and developing countries. They express a sense of place or identity within a city corridor. According to Zalina and Rodzyah (2012) expressed that the most preferred using area, is visiting places with a sense of place such as heritage streets. Above all, heritage building depicts the place identity and quality of people's lives in a community, district, city, and country at large. Therefore they deserved to be protected, preserved, conserved and specifically enhanced to a more status of quality and revival process. Indeed, the a optimum decision-making is needed to enhance the revival process.

Hence, whenever the decision-making and reuse of a particular or multiple built heritage assets arises, it is associated with complex decisions and alternative questions such as (1) should the asset be demolished or not to, (2) which the best method is needed to be applied to the building, (3) which building should be reused, (4) or have more potential, and (5) how the design criteria of heritage asset can be integrated into use (Henehan and Woodson, 2004). Kincaid (2002) suggests that adaptive reuse is a complex process which requires participants in the process that have the potential understanding on how to determine the most appropriate future of a building in respect to a particular time and location. Indeed, a collaborative dedication and rigorous effort of several complex decisions carefully identified and resolved at a preliminary stage before further intervention will definitely yield a quality implementation.

Contemporarily, there are several models that intervene decisions and proper reusing of the built heritage assets commonly adopted in developed countries. They are known as the decision-making models. Hence, this paper is looking towards exploring the characteristics of these models enhancing the quality of built heritage assets,

\section{Problem Statement}

Nigeria has bounties of built heritage assets, ranging from tangible and intangible properties which can be grouped into natural and cultural attractions (Anyachonkeya, 2017). These heritage assets encompasses traditional, pre-colonial, colonial and colonially facilitated architypes with legacy potentials and valuable artifacts (Osasuna, 2015). Hence, these buildings deserved to be conserved, preserved, protected, reused and enhanced to subsequent future generations for the younger ones and point of reference. Consequently, this will promote the prevention of these valuable assets from becoming redundant, damaged, deteriorated, and demolished. Thereby avoiding falling into state of irreversible loss of heritage. At this point, the tradition and attitude of conservation, protection and reusing of redundant heritage properties in Nigeria is still largely in its infancy stage.

Contemporarily, developing countries including Nigeria, are facing challenges of rapid growth of population and urban or city development projects. In addition, as the building industry is fast moving to new levels of advance technology, the rapid development within 
cities is continuously emerging, engaged into modern architecture construction and redevelopment of building projects. Financing more resources and effort to improve the aesthetical value and image of cities. On the other hand, the historical value and useful life of heritage properties are under threat of becoming more ignored as a result of the urban renewal, transformations and planned new development projects by government and developers. Besides, attention and little knowledge on how to conserve and reuse obsolete buildings to suit new function is lacking by the government and the developers during the intervention projects.

Accordingly, as the historic buildings become more ignored, vacated and redundant due to unidentified new function to suit new condition, the heritage properties become obsolete and eventually destroyed for new project. Destroying and fading away of the valuable heritage properties will persist once a proper decision-making and reuse selection strategic movement is properly not juxtaposed with the contemporary development. Consequently, there will be creation of historical gap to subsequent generations. Moreover, irreversible losses of surviving credible pieces of evidences, artifacts, incidences \& knowledge of the past and sense of belonging by the younger generations, thereby declining the sense of identity.

Indeed, the intervention in connection with prime decision-making and proper reuse selection will enhance the conservation and restoration of the historic buildings to subsequent generations. At this juncture, there are available decision-making models and tools that aids in resolving set of complex consideration and proper evaluation in reuse selection of redundant heritage built assets adopted mostly in developed countries. However, these decision-making models and tools are scarcely acknowledged or less used in developing countries including Nigeria.

\section{Challenges of Conservation Practices in Reusing Historic Buildings Typology in Nigeria}

Nigeria is currently a developing country blessed with natural sites and beautiful scenes with historical significance both in tangible and intangible heritage. Moreover, as a colonized territory and developing country, it is largely embedded with old buildings, at pre-colonial and post-colonial period both in rural and urban areas. The conservation of these historic buildings is controlled and protected under the Cultural Heritage Legislation and Management (CHLM), which was consolidated in 1979. After then, the government proposed a subordinate agency known as the National Commission for Museums and Monuments (NCMM) Act. The Commission is responsible for cultural heritage management conservation, preservation, and restoration.

However, these laws are often offended in practice by destruction or unauthorized transformation or removal of monuments due to economic, rapid population, urban renewal projects \& political interest. For instance, a 161 year old declared National monument heritage property popularly known as the lloja Bar, popularly known as Case de Fernandez house, was senselessly destroyed to ground in Lagos, Nigeria on $10^{\text {th }}$ September 2016 . The building has legacy and embedded with a Brazilian architecture built with dedication and style 
built in 1855. Declared National Monument in 1956 officially by the National Commission for Museums and Monuments (NCMM).

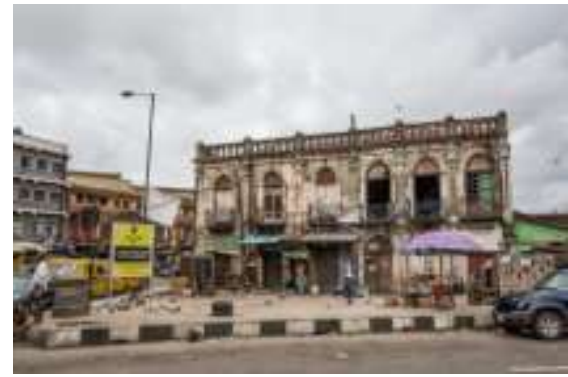

Figure 1: llojo bar building before demolition at Tinubu square, Lagos. (Source: Legacy Group, 2016)

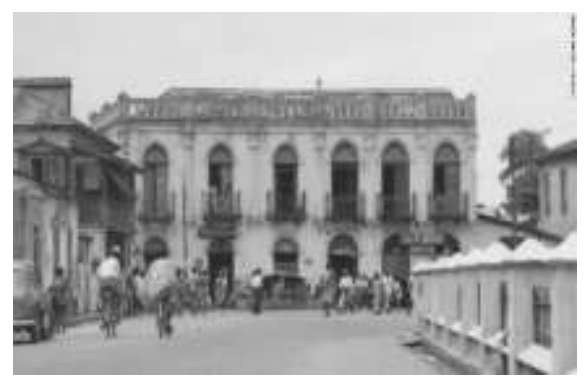

Figure 3: llojo bar building in 1955 (Source: CNN, 2017)

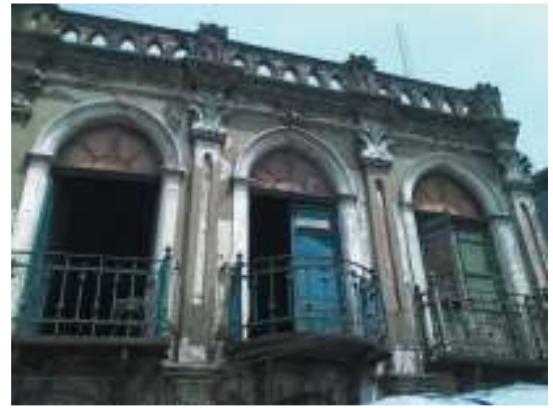

Figure 2: llojo bar building in state of disrepair

(Source: Osasuna, 2017)

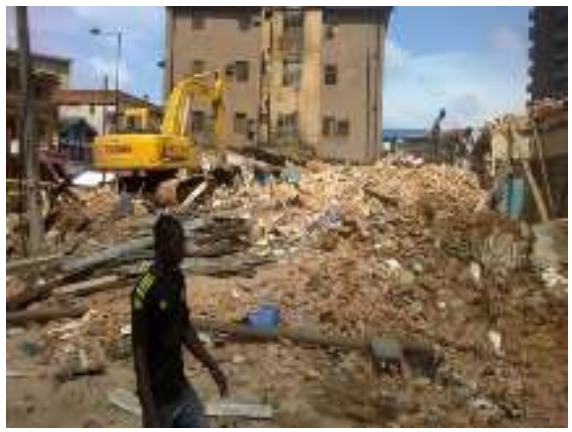

Figure 4: llojo bar building after demolition at Tinubu square, Lagos, Nigeria (Source: Legacy Group, 2016)

The Afro-Brazilian Architecture piece building, which stood on Tinubu Square, inside the city of Lagos in Nigeria and was the center of the community's social scene as seen in Figure 1. The building gives a glimpse of the history and serving a place of identity particularly as a landmark. Unfortunately, the building was abandoned for 60years, dilapidated to threat of demolition as seen in Figure 2. Consequently the heritage property was consciously grounded to rubbles without proper evaluation of proper reuse selection and immature decision-making, without adopting any model or tool before final decision. The continuous destruction of such properties will only lead to fading away the historical value, irreversible loss of pieces of evidences, permanent loss of belonging and identity as well as discontinuity of heritage inheritance, thereby tempering the quality life of the community. 


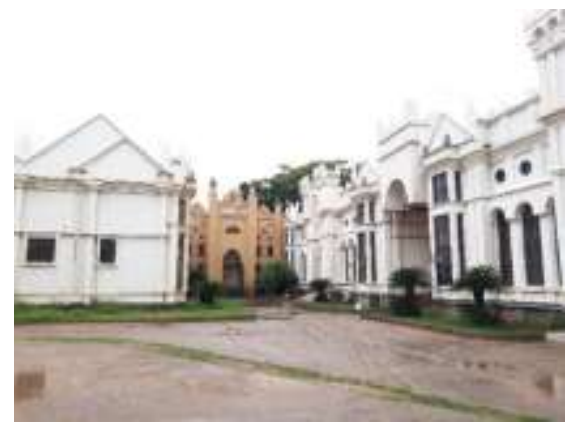

Figure 5: Gombe Emir Palace compound. (Source: author)

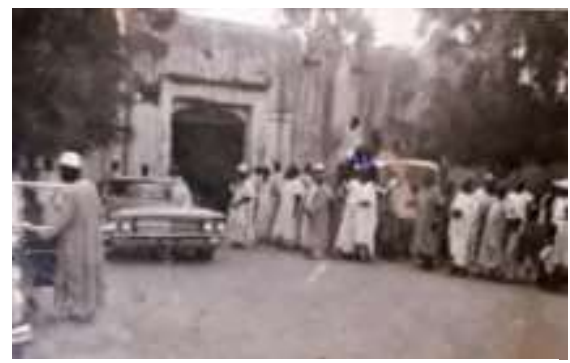

Figure 7: Gombe emir palace entrance foyer from the premises before demolition (Source: author)

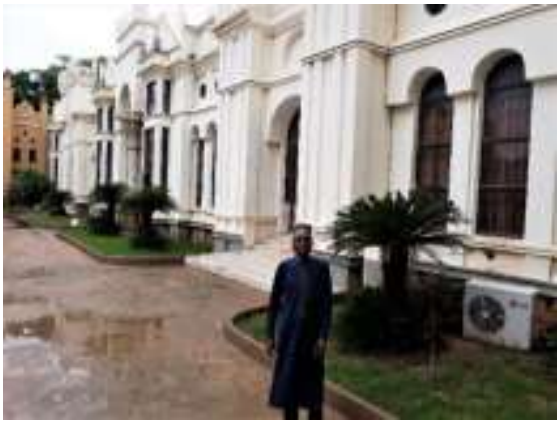

Figure 6: Gombe Emir Palace approach compound.

(Source: author)

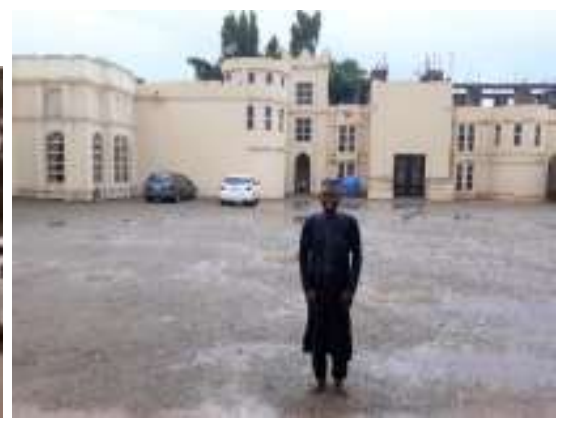

Figure 8: Gombe emir palace entrance foyer from the premises after demolition (Source: author)

Regrettably, the injudicious decision-making is gradually intervening into traditional palaces in Nigeria in their various cultural milieu. Despite the fact, traditional palaces should appear as cultural identity in the community upholding the cultural heritage as being a focal point in the environment. Indeed, conservation of palaces in its full authentic indigenous architecture shall be mandatory. Furthermore being an authoritative institute shall be conserved, blending with the cultural milieu to harmonize the traditional settlement. Besides, the conservation will be a credibility of a surviving evidence and historical knowledge of cultural heritage of the people. However, the ancient traditional palaces being built in mud with dedicative skills and effort are injudiciously being demolished and reconstructed with modern building materials due to contemporary architecture, modernization and unwise decision.

The decision would have been wise by reusing the old palace to serve and change into a new function by adapting the decision-making model. Thereafter, a new palace can be 
reconstructed separately. For instance, the Oonis palace was demolished from it mud structure and rebuilt with cement block (Omisore et al., 2009). Similarly, the long standing Gombe emir palace standing well fit in conducive and good condition was indujiciuosly demolished and totally eliminated, extremely short of its life span without any genuine reason. Equally the palace was transformed newly into a foreign identity as seen in figure 7 .

Above all, the obliteration processes of these cultural heritage properties will only lead to permanent loss of identity and sense of evolution. Besides, if well documentation before taking the destruction or changes is not taking place, not even a surviving credible pieces of evidences, artifacts, incidences \& knowledge of cultural heritage value will forever be known by the future generations.

\subsection{Purpose of the Study}

Historical buildings are built with available resources, materials and space to serve a particular purpose at a particular time and location. According to Silva and Henriques (2015), historic buildings are valuable assets left by history and able to witness some development through civilization, meaningful development or certain historical events, urban or rural environment. Meanwhile due to economic changes and industrial practices, demographic shifts, increasing cost of upkeep or maintenance, eventually the original intent of the historic building becomes redundant. Subsequently, becoming redundant might be inevitable because the population size has increased due to rapid growth. Therefore, demand of more functional space and arrangement of the interior is needed beyond the size of the historic structure built as at then. Secondly, the intent designed for the historic structure has become obsolete to the present generation within the milieu serving the community. Certainly, when the situation occurs, the building may be subjected to obsolescence and becomes vacated.

Accordingly, this will continue to reduce the life span of the buildings leading to deterioration and eventually demolished due to unidentified new function to revive the historic building and injudicious decision-making and proper reuse selection (Langston, 2012; 2014). At present, despite the fact that there are decision-making models and tools empirically adopted mostly in developed countries during decision-making and reuse selection of historic building. However, less utilization of these models are carried out in developing countries including Nigeria to conserve redundant built heritage assets during project intervention. Besides, inappropriate selection of new function might be implemented disordering the social environment, or injudicious decision might be delivered by obliterating the historic building to the ground recklessly.

Hence this paper is aimed at reviewing journal articles that empirically adopted the decision-making models and tools in mostly in developed countries to support the challenges of injudicious decision-making and improper reuse selection of historic buildings in developing countries. The findings and exploration of the methods of adopting with the models will enhance a revival process and quality in conserving the heritage built assets in the developing countries. Besides, the proper decision will tremendously reduce the demolition of the historic buildings extremely short of their live span. As it is generally known, the pride success and life quality of every community in a society is to refer to its history, to 
ensure the continuity of a common identity that evolves overtime. The objectives of this study is firstly to evaluate substantive findings of the decision-making models, discovering common and different characteristics of the decision-making model and tools. Secondly, to explore the advantages and limitations of the identified models and tools. Finally, to acknowledge the practical implications of the models and their limitations for future recommendations.

\subsection{Significance of the Study}

Siti et al., (2016) suggested that in the process of reusing heritage building to perform functions, preservation of heritage buildings is ultimately needed. The preservation tremendously improves the social well-being and the happiness of the community. Equally, Bullen and Love (2009) mentioned that adaptive reuse may promote social inclusion and cohesion among stakeholders and community to reduce the cost of new development by destroying potential existing buildings short of their lives due to urban development activities. Other significances of heritage building adaptation, enhancing sustainability and quality of life can be seen in Figure 9.

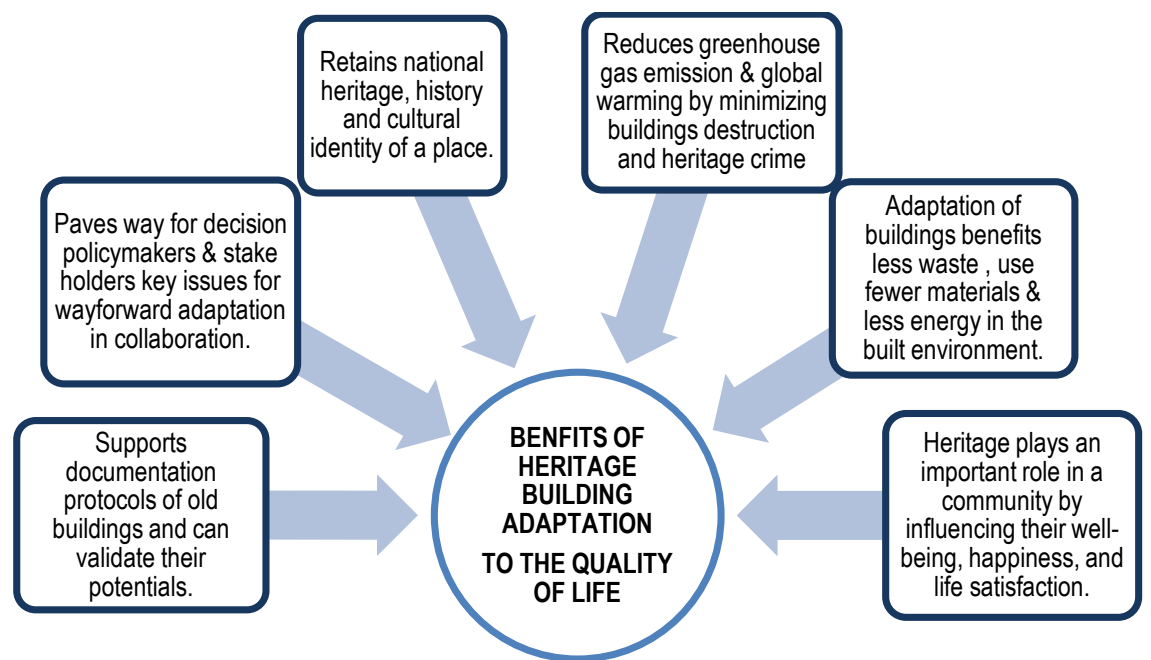

Figure 9: Benefits of Heritage building adaptation to a quality of life

Meanwhile, building adaptation is a phenomenon that promotes the deconstruction of the heritage buildings and at the same time support community participation in accomplishing a decision-making task successfully. Hence, collaborative planning and decision is the process that has to do with the engagement of relevant stakeholders to develop plans. These plans are drawn to with consensus reflecting all relevant interest of stakeholders .In addition, Azni and Nuraisyah (2013) also mentioned that empowerment, responsibility, and communication are key factors of effective participation. Particularly, empowerment is not about public's right but as well having influence in decision-making. According to Rodzyah 
M. Y et al., (2013) concludes that it is crucial for every decision we make should be a wise one. Hence, Wilkinson and Langston., (2014) conclude that for a successful adaptation and sustainability of buildings be accomplished, there should be rigorous repetition process of discussions and decisions before reaching final outcomes to be realized. Furthermore, due to the complexity of decision-making, to assist and simplify stakeholders and decisionmakers in reaching mutual concession, a framework and decision making tools are needed.

\subsection{Literature Review}

History is the study of the past as it is described in written documents. The pride success and life quality of every community in a society is to refer to their history. This is to ensure the continuity of a common identity that evolves overtime. Indeed, Heritage property is one of the tangible object and as well as an icon that retains history surviving as a souvenir in a milieu. As buildings can easily transfer history knowledge to people, community, or to a city at large from one generation to another. Indrawati (2008) mentioned that the history of a region is easily identified and recorded from historical heritage buildings. In addition, source of knowledge that has fundamental significance to a place identity is embedded within the heritage building fabric (Widodo, 2000). Therefore, presence of heritage property makes it possible for the present generations to understand their place in history. Nurlisa and Vinky (2016) strongly suggests that it is necessary for every city to conserve and preserve the useful life of its heritage properties, to keep the place identity intact due to the rapid growing population. Indeed, heritage buildings play a significant role in the social, historic, cultural and economic dynamics of every country, as they express a sense of place or identity within a city corridor. Nowadays, the preference of adapting and reusing cultural and heritage buildings rather than abandoning and destroying them is worldwide fast growing and accepted in developed countries (Ball, 1999; DEH, 2004; Wilkinson and Reed, 2008; Wilkinson et al., 2009; Bullen and Love, 2009).

Buildings may become redundant for various reasons, such as changing of economic and industrial practices, demographic shifts, increasing cost of up keeping or maintenance. Mostly because they are no longer suited for the original function and new use has not been identified (Orbasli, 2008). According to Langston (2012) posits that, rather than vacating and demolishing of buildings that are obsolete short of their lives and use as material waste. Instead, it is rather more effective solution to leave the basic structure and fabric of the building intact then objectively change its use to suit new condition. This approach is called adaptive reuse, thereby breathing new life into existing building, sustaining it to the next generation. Douglas (2006) also takes the view that adaptive reuse, is a phenomenon that involves stages of procedure in altering the capacity, original purpose or performance of any building work and intervene to adjust, reuse or upgrade the living standard of a building, to suit new conditions and requirements. For this reason, one of the sustainable strategy of promoting sustainability through conservation is by adaptive reusing it .As adaptive reuse is a phenomenon that can depict the life span of a building, by prolonging it through building conservation and innovation, meanwhile having minimum impact on the heritage 
significances on the buildings and its surrounding (Prihatmanti, 2015).

Therefore, Bullen \& Love (2010) asserts that adaptive reuse is one of the sustainable policy nowadays used in regenerating our existing buildings because it has the potentials of preventing the irreversible loss of heritage, protects the valuable environmental resources and promotes wise use of natural capital including renewable and non-renewable resources. In this case, Shahrul et al., (2013) comments that conservation is a process that involves repair, restoration, preservation, maintenance, repurposing and in particular adaptive reuse. Indeed, adaptive reuse is looked at possible measures in maximizing the longevity of buildings or optionally to reuse the building judiciously by injecting new functional changes (Dalia, 2004). In addition, heritage buildings are significant as they symbolize and give glimpses from related past periods. They should be sustained as evidence of the people's life style and cultural identity instead of destroying such buildings (Damla and Kagan, 2016). Ahmad E.H et al., (2012) further mentioned that historical buildings have architectural, aesthetic, historic, documentary, economic, social and political and symbolic values. Hence, According to Noorfadhilah and Shamzani (2012) cautioned that people/users tend to overlook the existing aesthetic, culture and architectural relics and intervene to modify the building to suit their requirement thereby slowly fading away the historical value and loss of identity. In this case Siti et al., (2016) suggested that in the process of reusing heritage building to perform functions, preservation of heritage buildings is ultimately needed. Hashimah and Ismail (2013) mention that the process of conserving heritage buildings is through recycling them for contemporary uses as seen in Figure 10. .

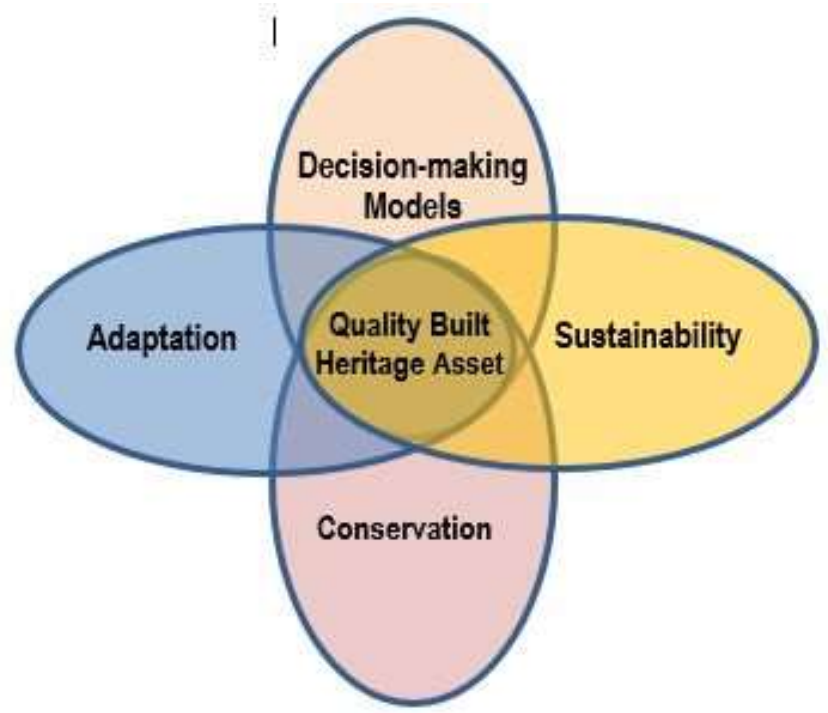

Figure 10: Revival Process Concept of the built heritage asset from the definition of terms 
In addition, the process of maintaining place identity of an area is through preservation, thereby keeping the urban heritage and sense of place intact. Likewise, Farhanah and Mohamed (2012) mentioned that conservation of heritage building is a process that has no exception to every country, as they functionally provide evidence of historical past, environmental setup, and heritage of the nation.Similarly, Hasnizan et al., (2016) comment that historical buildings do not only play a significant role representing the cultural identity and historical background but also serve as a source of generating income to the nation. For example, Salleh and Ahmad (2009) comments that conserving historical buildings through adaptive reuse are converted to commercial use from their original use as museums, libraries, offices, and hotels. Examples in Kano city, Nigeria, abandoned buildings adapted in use to suit new function such as warehouses to school classrooms, proposed hotel to an academic institute, former investment building to a state university, and office building into a private university. Therefore, building adaptation is a significant strategic phenomenon that enhances the quality of the historic buildings regenerating them to the future.

Hence, these buildings deserved to be conserved, preserved, protected, reused and enhanced to subsequent future generations. Consequently, this will promote the prevention of these valuable assets from becoming redundant, damaged, deteriorated, demolished, and permanent loss. Thereby avoiding falling into a state of irreversible loss of heritage. According to Adeyemi \& Bappa (2011), proper decision making by conserving historic buildings strengthens the five senses qualities of the community in their respective milieu. The senses of quality includes sense of place, sense of identity, sense of evolution, sense of ownership and sense of community.

\subsection{Methodology}

The research method of the study entailed a review of 40 journal articles and two book chapters. This is because the paper has a scope unto references related to decision-making models and to have a wide range of literature review that will support the paper in achieving its aim. Hence, the paper focuses on journals that published on decision-making models of built heritage assets through empirical studies mostly in developed countries where the conservation practice is found common. Besides, the major references cited in the paper are journal articles on adaptive reuse of historic buildings and as well conservation of heritage properties. The articles and books were sourced electronically from Science Direct (including AMER ABRA Procedia articles publications), Web of science, e-library, and Google Scholar. The multidisciplinary approach that contributed in the literature includes architecture, facility management, engineering, construction management, social sciences, history, and geography. Out of the 40 journal articles, eight (8) decision-making models were deduced and sampled. Furthermore, the implementation of these models adopted in the different journal articles from different part of location and region in the developed countries were recorded, including the method and characteristics implemented. Meta-analysis was conducted to explore the findings. The deduced 8 decision-making models were categorized into three domains in a tabular form into author/year/country; Model/paper title; study area 
for further meta-analysis as seen in Table 1 . The table depicts the evaluation of the substantive findings of the historical buildings decision-making models.

\section{Data collection}

The eight decision-making models deduced from the reviewed forty journal articles are seen in Table 1. The table showcases the research objective, evaluating the substantive findings of the decision-making models adopted and implemented in the developed countries. The table further lists each of the title paper of the reviewed articles and explaining their brief practical implications of the adopted model in the study area.

Table 1: Research findings

$\begin{array}{ll}\text { s/n } & \text { Author/Year/Country } \\ & \begin{array}{l}\text { Mousumi \& Zakir (2009) } \\ \text { (INDIA) }\end{array} \\ 1 & \\ & \quad \begin{array}{l}\text { Ignacio Pi neroa, José T. } \\ \text { San-Joséb,*, Patricia } \\ \text { Rodríguezc, Milagros M. } \\ \text { Losánez } \\ \text { (2017) (CUBA) }\end{array}\end{array}$

3 Ferretti, Bottero \&, Mondini (2014) (ITALY)

4 Huey-Jiun and

Zhi-Teng (TAIWAN)

(2010)

5 Bullen \& Love

(2011) (AUSTRALIA)

Model / Paper title
Multi-criteria Decision-
Making (MCDM)
Paper Title: An application of
Multicriteria Decision Making
to built heritage.
The case of Calcutta

Paper Title: Multi-criteria decision-making for grading the rehabilitation of heritage sites. Application in the historic center of La Habana

\section{Multi-Attribute Value Theory (MAVT) Paper Title: Decision making and cultural heritage: An application of the Multi- Attribute Value Theory for the reuse of historical buildings.}

\section{Analytic \\ Process(ANP)}

Paper Title: A multi-objective decision-making process for reuse selection of historic buildings

Adaptive Reuse Decision Making Model Paper Title: A New Future for
Study area

The tool was used in resolving complex decision between policymakers and stakeholders in Calcutta, India. To grade different heritage sites in order to find priorities for conservation and redevelopment.

The MCDM model was used in the center of La Habana, capital of Cuba for practical cultural protection of an urban zone. The urban zone was embedded with thousands of disrepair and abandoned buildings needing emergency of urban regeneration and redevelopment

In this research, MAVT has been applied in the metropolitan Turin (Italy)resolving problem decision about the reuse of a set of historical buildings. The tool provides resolving conflicting objectives and disagreement issues. It supports and provides a checklist of elements able to support planners and decision-makers in understanding which buildings are worthwhile to be preserved and conserved.

The tool is effectively efficient for resolving the reuse selection problems, particularly of interdependence criteria. The tool has been demonstrated its workability of reuse of historical two building in Taiwan.

The model was propagated in Perth, Western Australia.

It is model that provides a reference 
Umar, S.B., \& Said, I. / Asian Journal of Environment-Behaviour Studies (ajE-Bs), 4(12) Jan / Apr 2019 (p16-36)

the Past:

A Model for Adaptive Reuse

Decision-making

6

Conejos, Langston, \& Smith

(2013) (AUSTRALIA)

$7 \quad$ Langston et al. (2008)

(AUSTRALIA)

8 Assefa \& Ambler

(2017) (CANADA) environment
AdaptSTAR model

Paper Title: AdaptSTAR

model: A climate-friendly strategy to promote built

sustainability

Adaptive reuse potential model (ARP Model)

Paper Title: Strategic assessment of building adaptive reuse opportunities in Hong Kong

The Life Cycle Assessment (LCA)

Paper Title: To demolish or not to demolish: Life cycle consideration of repurposing buildings point in concluding a decision-making among stakeholders on demolition or reuse. As it provides check-list of key issues to arrive at the certain decision.

12 selected successful case studies in New South Wales (NSW) and Melbourne, Australia were taken into consideration. The model embeds a design decision into adaptive reuse projects during design conceptualization process.

The model predicts the useful life of a building for the intervention of potential reuse. High ARP scores have been shown to lead to superior economic, social and environmental benefits in practice via an Australian Research Council grant (2008-2010).

The project was carried to investigate and compare the potential life cycle environmental impacts of a Tower Library (MLT) in Canada that was under threat of demolition.

\subsection{Results and Discussions}

Eight decision-making models of built heritage assets were deduced from the 40 reviewed journal articles as seen in Table 2. The decision-making models of the built heritage asset include Analytical Network Process (ANP), Multi-criteria Decision-making (MCDM), MultiAttribute Value Theory (MAVT), Adaptive-reuse Decision-Making Model, AdapSTAR model, Adaptive Reuse Potential Model (ARP Model) and Life Cycle Assessment (LCA) model. The meta-analysis, explores the findings, describing the common and different characteristics of the decision-making model of built heritage assets adopted and implemented from the different part of the world mostly developed countries. The analysis further explains the methodological processes and the practical implication of each of the decision-making model during the intervention of reuse selection of the historical buildings in conserving the structure. First and foremost, the models resolves the decision-making problems in the same methodological revival process. Although, it is realized that there is formation of three groups of the models distinctively having distinguished mode of intervention in resolving decision problems during frame working along the methodological processes line as seen in figure 4 . The mode of intervention includes using mathematical equations, case studies and in-depth interviews, and software. The methodological processes involves three (3) stages from collaboration to implementation which involves teaming up of experts for collaboration, then frame working (resolving the decision issue through the mode of intervention), then finally the implementation after resolving the decision-making. Further details of the methodological 
revival process is seen in Figure 11 and 12.

In reference to Figure 4, firstly group 1 applies mathematical equation in their mode of intervention in resolving identified several alternatives of considered factors. The group entails four (4) decision-making models, including Analytical Network Process (ANP), Multicriteria Decision-making (MCDM), Multi-Attribute Value Theory (MAVT) and Adaptive Reuse Potential Model (ARP Model). Secondly, group 2 largely involves case studies and in-depth interviews in exploring and resolving considered factors from experts. The group entails two (2) models including Adaptive-reuse Decision-Making Model and AdapSTAR model. Then lastly, group 3 which is the Life Cycle Assessment (LCA) model employs software known as EcoCalculator 3.7.1 to forecast the impact of demolition during intervention analysis.

Table 2: The advantages and limitations of the deduced decision-making models

$\begin{array}{llll}\mathrm{S} / \mathrm{n} \text { Model Method Advantages and LIMITATIONS } & \text { Further } \\ & & \text { Research }\end{array}$

$\begin{array}{llll}\text { Analytical } & \text { Experts } & + \text { Evaluates and } \\ \text { Network } & \text { Interview } & + \text { resolves identified } \\ \text { Process } & \text { Saaty's } & \text { multiple criteria that } \\ \text { (ANP) } & \text { Supermatrix } & \text { are interdependent } \\ & \text { equation } & + \text { to each other } \\ & \text { Analytical } & \\ & \text { Hierarchy } \\ & \text { Process }\end{array}$

The tool does not evaluate criteria where there is no interdependence.

For the further application, a software can be developed on the basis if the tool.

2 Multi-criteria Decisionmaking (MCDM)

Multi-
Attribute
Value
Theory
(MAVT)

Experts + Value Function/index Equation

Experts + Participants + Interview \& questionnaire + Value functions (mathematical representation of human judgments).

Experts +

Athena

EcoCalculator 3.7.1
Evaluate and assess in ranking or priority result

Evaluates and resolves identified multiple criteria on basis of conflicting objectives and disagreement that have options

Forecast the benefit and environmental impact of a project on demolition or reuse decision debate.

Predicts useful life of

Program Evaluation and Review a building by assessing the
The tool does not take acknowledge value preferences of decision makers.

The tool acknowledges the criteria of any given objectives that have different measurement scales

In the empirical study then, only a few of the building components were not assessed and as they are not available in the software,

EcoCalculator. Identifies adaptive reuse potentials of existing buildings in
Development of Fuzzy MCDM model to rank heritage sites more proper. It is expected to look forward and consider the uncertainty of predictions and risk attitude of decision makers switching

It is recommended to look forward to life cycle assessment covering both at use phase and detailed end-oflife. 
Umar, S.B., \& Said, I. / Asian Journal of Environment-Behaviour Studies (ajE-Bs), 4(12) Jan / Apr 2019 (p16-36)

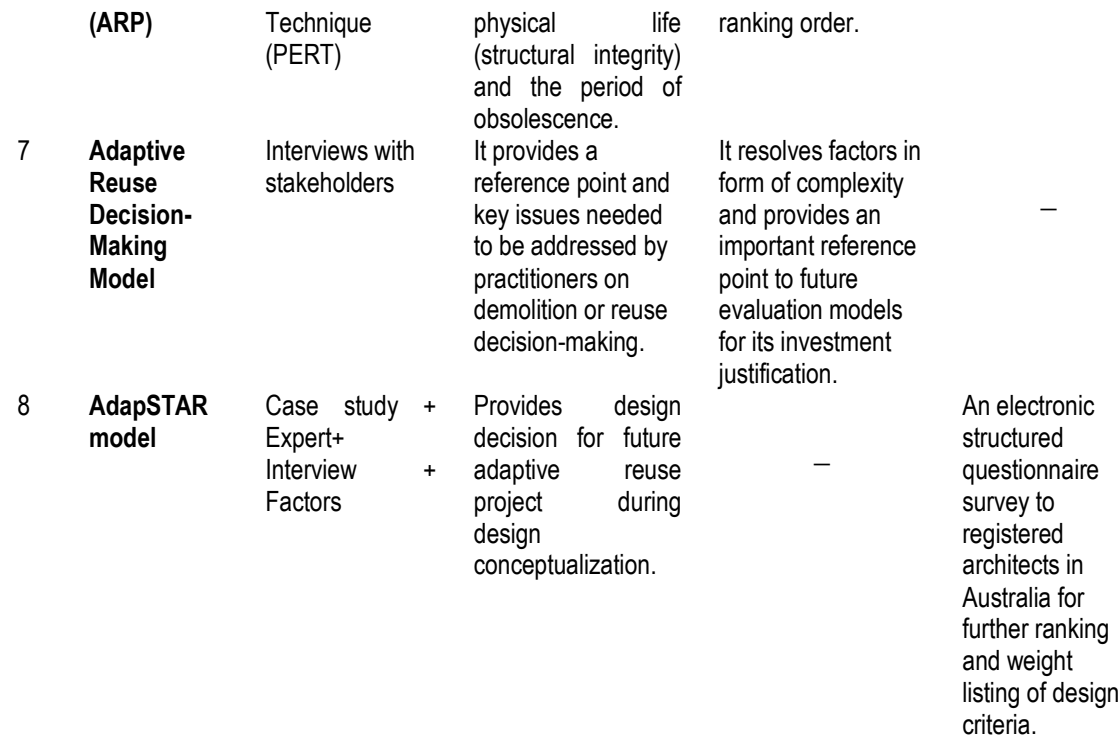

\section{Stage 1: Collaboration}

The collaboration stage is the process that involves developing of project team of relevant experts which may include owners, community, project stakeholders, and policymakers (government), depending on the project or historical building to be intervened for conservation in the social environment.

\section{Stage 2: Frame working}

This stage involves two steps. The first step is to identify sets of unresolved considered criteria (example, architectural aspect, economic aspect, cultural aspect, historical aspect, the social aspect, continuity aspect, and environmental aspect) understanding their complex relationships. Then, the second step is effective to optimize the best reuse selection options which will be integrated with the resolved criteria in the first step previously. The Four (4) decision-making models as mentioned earlier, including the Analytical Network Process (ANP), Multi-criteria Decision-making (MCDM), Multi-Attribute Value Theory (MAVT) and Adaptive Reuse Potential (ARP) resolve the identified considered several objectives using mathematical equations in a unique methods, series of processes and steps differently among the tools. For instance, in this review, the Analytical Networking Process (ANP) tool used the basic Matrix manipulation (Saaty's Supermatrix) in resolving the weights and impact of the criteria that are interdependent to each other. 


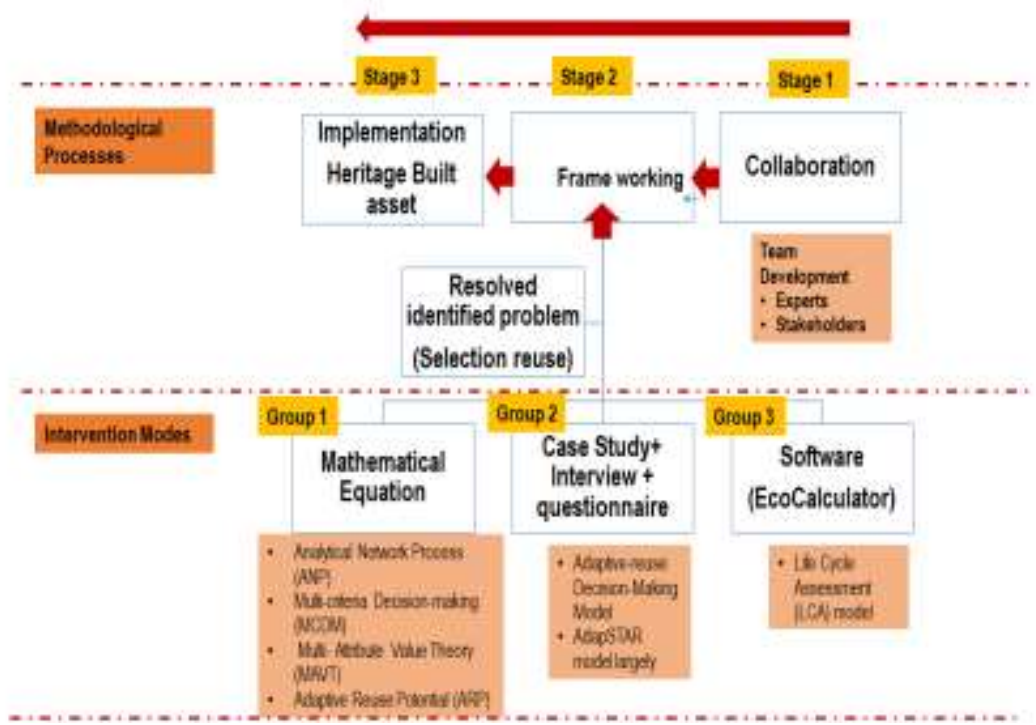

Figure 11: Decision-making models Methodological processes

(Source: Author)

While the Multi-criteria Decision-making (MCDM) adopts a means of mathematical value equation method or index by further making a comparative assessment of several alternative criteria in form of complexity. Example, heterogeneous measures or projects mixed with merits and drawbacks, or selecting options that are ranked by policymakers or stakeholders. For example, in Lahabana Cuba, a heritage cultural protection of an urban zone was brought up by the government with many degraded buildings that were in a condition of risk to collapse. As a result of applying the MCDM model, 1033 buildings were in need of emergency action, 169 awaiting demolition, 597 in need of urgent repair. Finally, Multi-Attribute Value Theory (MAVT) in this review, used the additive model simply represented in an equation to resolve set of alternative actions that have to be evaluated on the basis of conflicting objectives and disagreement among the stakeholders. For example in this review, five conflicting objectives were identified to resolved reuse selection of seven historical industrial buildings in Italy. The objectives include quality of context, economic activities, the flexibility of buildings, accessibility, and conservation level. Eventually, one of the building out of the seven turned out to be the best on the basis of weight ranking of the aforementioned objectives.

Then Adaptive Reuse Potential (ARP) is a model that predicts the useful life of a building by assessing the physical life function (structural integrity) and obsolescence to balance or evaluate the potential of the building. Due to the fact that obsolescence objectively reduces 
the useful life of a building. The model mathematically uses the Program Evaluation and Review Technique (PERT) in assessing the range of obsolescence to determine the building potentials known as ARP score $(\%)$. The model will now determine whether to reuse the built asset either long term or short term. 64 adaptive reuse projects were globally conducted using this model successfully. Therefore ARP model is considered a robust strategic model and widely accepted. For example, an urban renewal project of shop houses under threat of demolition led by the government in Hong Kong. When the ARP model was tested upon the historical traditional shop houses about eight shops were found with high potentials and saved from demolition. The model resolved decision-making by retaining the place identity of the community by preserving the few shop houses.

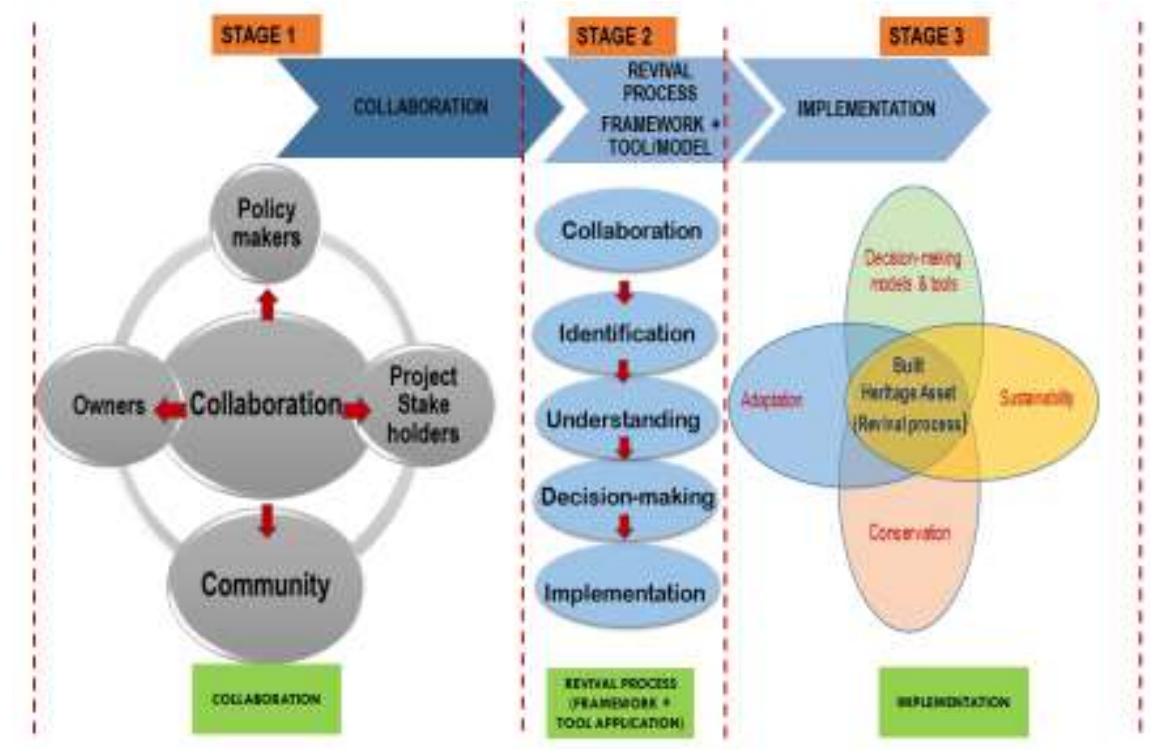

Figure 12: Methodological revival processes of the historical building Decision-making Models (Source: Author)

Followed by the Adaptive Reuse Decision-Making Model, which is a model purposely invented to provide a room in concluding a debate on decision-making on whether to reuse or demolish a built asset. The model bridges the gap between owners, project stakeholders and policymakers arriving at a point of reference. The proposed model identifies key adaptive reuse issues needed to be addressed and reviewed by the owners, project stakeholders, and policymakers. The key issues include 3 factors, Capital investment (owners), asset condition (project stakeholders) and Regulations (policymakers). Once these issues are addressed in reference to the built heritage asset through the model, the verdict on whether to demolish or reuse the built asset will practically be determined, then implementation takes place 
thereafter. Then AdapSTAR model is a design evaluation tool that upholds to make purposeful design decision during design conceptualization to assess the adaptive reuse potentials of future buildings. The determining factors the model is relying on the 7 factors of obsolescence which are political, social, economic, legal, environmental, physical and technological. Meanwhile, to make the model more effective and reliable, the tool is validated by ARP model to support and function as a weighted checklist of design strategies that leads to future successful adaptive reuse.

Finally the Life Cycle Assessment (L.C.A) among the deduced tool forecast the benefit and environmental impact of a building project. Especially, if a building is in a state of a decision on whether to demolish or reuse by repurposing. In this review paper, the tool uses/employs EcoCalculator, a software that can further assist in understanding the potential benefits and environmental impacts of a repurposing project with the goal of informing future building stock management. The tool works by thoroughly assessing both every building component and spaces to evaluate the resulting impact. The impact result is in percentage (\%).Example, When the LCA was employed and intervened, about $33 \%$ of global warming and $34 \%$ fuel consumption impacts respectively were avoided by not demolishing a Library tower in Canada rather was repurposed and reused.

\section{Stage 3: Implementation}

On the whole, having identified and resolved the prime reuse decision-making by proper evaluation, next is the implementation of the final stage. This is the stage of implementing the prime reuse decision-making of the built heritage assets during the conceptualization into practice by conservation through adaptation and enhancing the sustainability and quality of the built heritage assets improving the quality of life as seen again in the Figure 1 and 12. Hence, each of the different tool and model that has been proposed/adopted and implemented in an empirical study plays a significant role and benefit in enhancing the reuse selection problem of heritage buildings. Although, each and every of the tool has its advantages and limitations. Therefore, the limitation of one model will bridge a gap when combined with another model to achieve an optimum and qualitative decision-making and ultimate reuse selection.

For instance, in the center of La Habana, capital of Cuba for practical cultural protection of an urban zone. The urban zone was embedded with thousands of disrepair and abandoned buildings needing emergency of urban regeneration and redevelopment. As a result, when MCDM was employed, 3593 antiquated buildings were identified, where 1033 buildings need emergency action, 169 buildings awaiting for demolition, and finally 597 buildings are in need of repair.

Hence, since there are limitations for each models, adopting multiple models will yield to an optimum decision as seen in Figure 13. Firstly, for the 1033 buildings in need for emergency, can be treated with ANP, MAVT, ARP models. Hence, the ANP model will easily recover and resolve the best reuse selection choice for each building to suit new condition. Then, the MAVT model will aid the government project in determine the buildings to be treated with immediate actions based on budget. As the MAVT tool will expose all the building 
in ranking order base on priority to ease the intervention. Then finally, the ARP model will furthermore predict the useful life span of the building ranked by the MAVT to ascertain the physical life and know the potentials of each ranked or identified building. Consequently, the model will now determine whether to reuse the built asset either for a long term or short term. Secondly, for the 169 identified building awaiting for demolition, the LCA model can be employed to forecast the benefit and environmental impact of the building on whether the building deserves to be demolished or not. Lastly, the 597 building that are in need of repair can be referred to the TOBUS software, which will systematically diagnosis the building and aids in decision-making for the retrofitting intervention.

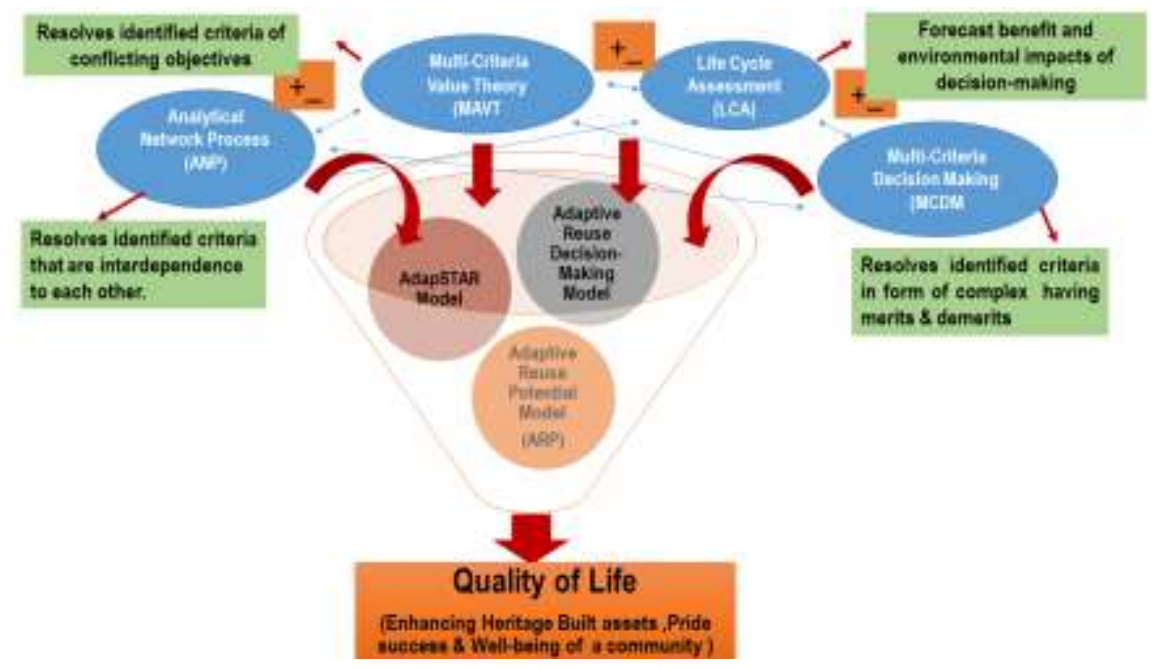

Figure 13: Future research possibilities

\section{References}

Adeyemi, A., and Bappah, B. A. (2011). Conservation of Kano ancient city wall and gates: problems and prospects in Nigeria. Journal of Environmental Issues and Agriculture in Developing Countries, 3(2), 80.

Ahmad E.H., Hasnizan A., Shahrul Y.S. (2012). Functional Assessment through Post Occupancy Review on Refurbished Historical Public Building in Kuala Lumpur. Procedia- Social and Behavioral Sciences, 68, 330 - 340.

Anyachonkeya Ngozi (2017), The English Language and Tourism in Nigeria. Melting Pot, 3, 1.

Azni Mohd Dian and Nuraisyah Chua Abdullah (2013). Public Participation in Heritage Sites Conservation in Malaysia: Issues and Challenges, Procedia- Social Behavioral Sciences, Vol. 101, pp 248-255.

Bullen, P.A. \& Love, P.E.D. (2009). Residential Regeneration and Adaptive Reuse: Learning from the Experiences of Los Angeles", Structural Survey, Vol. 27 No. 5, pp. 351-60. 
Bullen, P. A., \& Love, P. E. (2010). The Rhetoric of Adaptive Reuse or Reality of Demolition: Views from the field". Cities, 27(4), 215-224.

CNN (2017), Lagos Afro-Brazilian Architecture Faces Down the Buldozers. Retrieved from <img alt="llojo Bar in Tinubu Square is now demolished. It was once the center of the Afro-Brazilian community. "class="media_image" src="//cdn.cnn.com/cnnnext/dam/assets/170718103650-ilojo-bar-tinubu-nigeria-large-169.jpg">

Clough, G. Wayne, Jean-Lou Chameau \& Carol Carmichael (2006). Sustainability and the University: The Presidency.

Craig Langston (2008). On Archetypes and Building Adaptive Reuse. School of Sustainable Development, Bond University, Gold Coast

Craig Langston (2012). Validation of the Adaptive Reuse Potential (ARP) Model Using iconCUR. Facilities, Vol. 30, 3/4, pp.105-123. Procedia- Social and Behavioral Sciences, 105, 418-428.

Dalia, E. A. (2014), Assessment of the Compatibility of New Uses for Heritage Buildings: The Example of Alexandria National Museum, Alexandria, Egypt. Journal of Cultural Heritage, 15(5), 511-521.

Damla Mısırlısoy \& Kăgan Günce (2016). Adaptive Reuse Strategies for Heritage Buildings: A Holistic Approach. Sustainable Cities and Society, 26, 91-98

Douglas J. (2006). Building adaptation (2nd edition). London: Elsevier.

Falola, T., \& Heaton, M. (2003). A History of Nigeria. Cambridge University Press. 978-0-521-86294-3.

Farida S., Youcef C., \&Said M., (2016). The HQDIL Method to Assess the Sustainability of a Historic Center Case of Mansourah K'bira (Algeria). Procedia- Social and Behavioral Sciences, 216, 570-577.

Getachew A., Chelsea A. (2017). To Demolish or Not To Demolish: Life Cycle Consideration of Repurposing Buildings. Sustainable Cities and Society, 28,146-153.

Hasnizan A., Abdul Hadi N., Ahmad E. H., \& Elma D., (2016). Assessing Score of Applicability and Importance on Functional Performance Criteria for Historical Building. Procedia- Social and Behavioral Sciences, 222, 65 - 74.

Ignacio P., José T. S., Patricia R., Milagros M., (2017). Multi-Criteria Decision-Making for Grading the Rehabilitation of Heritage Sites. Application in the Historic Center of La Habana. Journal of Cultural Heritage, 26, 144-152.

Indrawati, Yanthi L, 2008.Peranserta Stakeholder Dalam Revitalisasi Kawasan Keraton Kasunanan Surakarta. TugasAkhir. Universitas Diponegoro. Semarang.

Henehan D, Woodson RD (2004). Building in Change of use: Renovating, Adapting and Altering Commercial, Institutional and Industrial

Properties. McGraw-Hill

Huey-Jiun W., Zhi-Teng Z. (2010).A Multi-Objective Decision-Making Process for Reuse Selection of Historic Buildings. Expert Systems with Applications, 37, 1241-1249.

Kincaid D., (2002). Adapting Buildings for Changing Uses: Guidelines for change of use refurbishment. London: Spon Press.

Liliane W. (2014). Adaptive Reuse: Extending the Lives of Buildings. 
Mousumi D., Zakir H., (2009). An application of Multi-criteria Decision Making to built heritage. The case of Calcutta. Journal of Cultural Heritage, 10, 237-243.

Nik Farhana Nik Azhari \& Embong Mohamed (2012). Public perception: Heritage Building Conservation in Kuala Lumpur. Procedia- Social and Behavioral Sciences, 50, 271-279.

Noorfadhilah M. B. \& Shamzani A. M. D., (2012). Documentation and Conservation Guidelines of Melaka Heritage Shop houses. Procedia- Social and Behavioral Sciences, 50, 192 - 203.

Nurlisa G. \& Vinky N.R., (2016). Maimoon Palace Heritage District in Medan Indonesia: What we Preserve and Why we Preserve. Procedia- Social and Behavioral Sciences, 222, 332-341.

Omisore, E. O., Ikpo, I. J., \& Oseghale, G. E. (2009). Maintenance survey of cultural properties in lle-lfe, Nigeria. Journal of Building Appraisal, 4(4), 255-268.

Orbasli, A. (2008), Architectural conservation, London: Blackwell publishing.

Osasuna, C. O. (2015). Heritage Architecture As Domestic Space: A Tale Of Three Buildings In lle-ife, Nigeria. International Journal of Sustainable Development and Planning, 10(1), 42-65.

Osasuna, C.O.( 2017), Nigerian architectural Conseravtion: Case for Grass-roots Engagement for Renewal. International Journal of Heritage Arhitecture, 1 (4), 713-729.

Peter Bullen and Peter Love (2011). A New Future for the Past: A Model for Adaptive Reuse Decision-Making. Built Environment Project and Asset Management, Vol. 1 Issue: 1, pp.32-44.

Prihatmanti R., (2015). The Impact of Adaptive Reusing Heritage Building as Assessed by the Indoor Air Quality. Case Study: UNESCO World Heritage Site Penang. Procedia- Social and Behavioral Sciences, 179, 297-307.

Rodzyah M.Y., Zalina S., Norezatty M.Y. \& Dasimah O., (2013), Expert Choice for Ranking Heritage Streets. Procedia-Social and Behavioral Sciences, 101, 465-475.

Salleh, N. H., \& Ahmad, A. G. (2009). Fire safety management in heritage buildings: The current scenario in Malaysia. 22nd CIPA Symposium. Kyoto, Japan. Retrieved November 4, 2014, from https://www.google.com.my/url?sa

=t\&rct=j\&q=\&esrc=s\&source=web\&cd=2\&cad=rja\&uact=8\&ved=0CCcQFjAB\&url=http\%3A\%2F\%2Fcipa.icomos.or g\%2Ffileadmin $\% 2 \mathrm{~F}$

template\%2Fdoc\%2FKYOTO\%2F11.pdf\&ei=jgihVLWzNoOTuASe64DICQ\&usg=AFQjCNFatm0IWKrT0jBalXoS2Q JcXUzCBw\&sig2=7Mt9gb68d4evT2I_Q8h2OA\&bvm=bv.82001339,d.c2E

Sheila C., Langston C., Smith J., (2013). AdaptSTAR model: A climate-friendly strategy to promote built environment sustainability. Habitat International, 37, 95-103.

Shahrul Yani Said, Hasnizan Aksah, \& Elma Dewiyana Ismail (2013). Heritage Conservation and Regeneration of Historic Areas in Malaysia. Procedia- Social and Behavioral Sciences, 105, 418-428.

Silva, H.E., and Henriques, F.M. (2015).Preventive Conservation of Historic Buildings in Temperate Climates :The importance of a risk-based analysis on the decision-making process. Energy and Buildings, 107, 26-36

Silviogiove, Paolorosato \& Margaretha (2011). An Application of Multicriteria Decision Making to Built Heritage. The Redevelopment of Venice Arsenal. Journal Of Multi-Criteria Decision Analysis, 17: 85-99. 
Umar, S.B., \& Said, I. / Asian Journal of Environment-Behaviour Studies (ajE-Bs), 4(12) Jan / Apr 2019 (p16-36)

Siti S. O., Siti R. Md Sakip, Norizan Mt A., (2016). Bringing the New to the Old: Urban regeneration through public arts. Procedia- Social and Behavioral Sciences, 50, $192-203$.

Wan Hashimah Wan Ismail (2013). Preservation and Recycling of Heritage Buildings in Malacca. Procedia- Social and Behavioral Sciences, 85, 574 - 581.

Widodo Sugeng, (2000). Studi Pelestarian Kompleks Masjid Menara Kudus dan Kawasannya.Suaka Peninggalan Sejarah dan PurbakalaPropinsi Jawa Tengah.

Wilkinson, S. J., \& Langston, C., (2014). Sustainable building adaptation: innovations in decision-making. John Wiley \& Sons. 